\title{
Combating Varroa destructor in Honeybee Colonies Using Flumethrin or Fluvalinate
}

\author{
A. GREGORC, M. I. SMODIŠ ŠKERL
}

Agricultural Institute of Slovenia, Ljubljana, Slovenia

University of Maribor, Faculty of Agriculture, Maribor, Slovenia

Received May 31, 2006

Accepted February 20, 2007

\begin{abstract}
Gregorc A., M. I. Smodiš Škerl: Combating Varroa destructor in Honeybee Colonies Using Flumethrin or Fluvalinate. Acta Vet. Brno 2007, 76: 309-314.

Mite mortality in two apiaries, one with 32 and the other with 15 honeybee (Apis mellifera carnica) colonies, was recorded prior to and after flumethrin or fluvalinate treatments and after a control, oxalic-acid application. During the 42- and 51-day pre-treatment periods, the average daily natural mite drop was $0.04( \pm 0.04)$ and $2.82( \pm 2.19)$, respectively, which represents $1.09 \%( \pm 1.06)$ and $3.84 \%( \pm 3.04)$ of the total number of mites found during the experiment. The flumethrin or fluvalinate applications resulted in an average mite mortality at the two apiaries of $214.46( \pm 260.02)$ and 4,098.64 $( \pm 2,508.31)$. The treatments resulted in a $19.11 \%( \pm 14.62)$ and a $39.28 \%( \pm 10.47)$ reduction in the number of mites in slightly infested colonies and $94.30 \%( \pm 4.26)$ and $96.24 \%$ $( \pm 3.14)$ in highly infested colonies. The difference in treatment efficacy between both apiaries was significant $(P<0.001)$ and indicates that fluvalinate and flumethrin are highly efficacious in dealing with highly infested honeybee colonies with sealed brood. The importance of effective mite control in colonies with a high level of natural mite mortality is discussed in this study.
\end{abstract}

Acaricides, control methods, Apis mellifera, oxalic acid, mite infestation

Acaricides are regularly applied to honeybee colonies in order to maintain their productivity. These are usually synthetic and their lipophilic and persistent characteristics result in a build-up of their residues in the wax and honey (Wallner 1999).

The varroa mite has already developed a resistance to several synthetic acaricides (Milani 1999; Lodesani et al. 1995; Miozes-Koch et al. 2000; Floris et al. 2001; Spreafico et al. 2001) and beekeepers are increasingly turning to alternative treatments incorporating essential oils and organic acids (Mutinelli et al. 1997; Melathopoulos and Gates 2003; Gregorc and Poklukar 2003).

The efficacy of fluvalinate and flumethrin in killing mites is long-lasting. Fluvalinate is available under the trade names Apistan (used against varroa mites in bee colonies), Klartan and Mavrik, while flumethrin is available under the trade name Bayvarol, which is specific for varroa control. Oxalic acid (OA) has been found to be highly effective in treating colonies without brood (Imdorf et al. 1997; Brødsgaard et al. 1999). Efficacy of $95 \%$ was achieved after three treatments using a 5\% OA solution (Mutinelli et al. 1997) and efficacy of $24 \%$ after one springtime treatment administered by trickling when a capped brood was present (B $\varnothing \mathrm{dsg}$ aard et al. 1999). In our previous experiments the quantity of OA solution used to treat one normally developed colony was approximately 50 millilitres and we found that three OA treatments of colonies with brood had efficacy of $39.2 \%$, and 99.4\% when there was no brood present (Gregorc and Planinc 2001 and 2004a).

This study was designed to evaluate the effectiveness of fluvalinate and flumethrin against varroa mites in honeybee colonies with sealed brood that are treated with oxalic acid during the period without brood.

Data gathered during the experiment, such as the number of dead mites that had fallen onto the metal sheets at the bottom of the hives, was used to determine mite mortality both prior

Address for correspondence:

Prof. dr. Aleš Gregorc

Agricultural Institute of Slovenia

Hacquetova 17, 1001 Ljubljana

SLOVENIA
Phone $+3861 / 280-51-50$

Telefax +3861/280-52-55

E-mail: ales.gregorc@kis.si

http://www.vfu.cz/acta-vet/actavet.htm 
to and after both treatments. The objectives of this study were to evaluate the acaricidal efficacy of the treatments on honeybee colonies and their effects on the mite mortality rate as well as to establish the residual efficacy of both treatment methods.

\section{Materials and Methods}

Two apiaries, one with 32 and the other with 15 honeybee (Apis mellifera carnica) colonies populated in national standard AŽ "back load" hives (Zdešar 1998), were located at sites in Senično and Lesce, in the Gorenjska region of Slovenia, which is influenced by continental climatic conditions. The hives had ten $41 \times 26 \mathrm{~cm}$ combs in each of the brood and honey compartments and $38 \times 29.8 \mathrm{~cm}$ metal sheets were inserted on to the hive floors in the spring of 2005 in order to record natural mite mortality. Wire screens above the sheets prevented bees from coming into contact with the debris. On the sampling dates, the number of mites was recorded and the inserts were emptied. The level of mite drop in each colony was recorded both before and after the fluvalinate and flumethrin treatments and after the treatment with oxalic acid. While the pre-treatment periods of the two apiaries were different - 42 days in one apiary and 51 days in the other, each was checked and cleared four times during this time.

The first treatment of thirty-two colonies took place on July 21, after the honey had been harvested. Seventeen colonies each received four polyethylene strips containing $3.6 \mathrm{mg}$ flumethrin (Bayvarol), while the remaining fifteen colonies each received two polyvinyl chloride strips containing $0.8 \mathrm{~g}$ tau-fluvalinate (Apistan). Seven of the fifteen colonies of the second apiary also received four Bayvarol polyethylene strips and the other eight colonies received two of the Apistan polyvinyl chloride strips. These strips were removed from the Senično and from the Lesce apiary on August 30.

A final treatment was applied to all the colonies on November 11 when there were no broods present in the colonies. Mites were counted on December 8, 27 days after final OA treatment. Fifty millilitres of a 2.9\% OA and $31.9 \%$ sucrose in water solution (w/w), which comprised oxalic acid dihydrate (Riedel-de Haen), sucrose (sugar) and de-mineralised water (Gregorc and Planinc 2001), was applied to every colony of the Senično and Lesce apiaries. During the application of the $\mathrm{OA}$ treatment the outside temperatures ranged from $5{ }^{\circ} \mathrm{C}$ to $8{ }^{\circ} \mathrm{C}$ and the operator wore a respiration mask, protective glasses and rubber gloves.

The number of natural mite drops in pre-treatment periods or killed by the flumethrin or fluvalinate treatments during the brood period was estimated by counting the mite "drop-down" $(\mathrm{T})$. The following formula was used to estimate the percentage of mites killed (PMK) by the treatments that began on July 21, 2005:

$\mathrm{PMK}=(\mathrm{T} /(\mathrm{T}+\mathrm{OA}) \times 100) \%$

The same formula was modified to calculate the percentage of mites that dropped before the treatments or after the removal of the medicated strips, as residual efficacy by excluding the number of mites collected in previous counts and in the first treatment.

Colony strength and behavioural changes in the bees were evaluated visually and both treated groups compared. Data analyses were carried out by ANOVA (analysis of variance) with the aid of the Statgraphics programme (1991).

\section{Results}

Mite mortality

During the pre-treatment periods, 42 days in Senično and 51 days in Lesce, the average daily natural mite drop was $0.04( \pm 0.04)$ and $2.82( \pm 2.19)$, respectively. The daily mite drop of the Senično apiary peaked at 0.14 and at 8.68 in the Lesce apiary. The percentage of mites that dropped during the pre-treatment periods at both locations was $1.09 \%( \pm 1.06)$ and $3.84 \%$ ( \pm 3.04$)$ of the total number of mites found during the experiment. These values were not significantly different $(P>0.01)$. Mite mortality in the pre-treatment periods and after treatments is shown in Table 1.

The flumethrin and fluvalinate applications on July 21 resulted in an average mite mortality of $214.46( \pm 260.02)$ per colony in Senično and of 4,098.64 $( \pm 2,508.31)$ mites in the Lesce apiary. In both apiaries the number mites that died after the treatments was significantly higher $(P<0.01)$ than the natural mite mortality.

The efficacy

The flumethrin and fluvalinate treatments on July 21 resulted in reducing the mite populations in the period between July 21 and November 11 by $19.11 \%( \pm 14.62)$ and $39.28 \%( \pm 10.47)$ respectively in the Senično colonies and by $94.30 \%( \pm 4.26)$ and $96.24 \%( \pm 3.14)$ in the Lesce apiary. The mortality rates triggered by fluvalinate treatment were significantly higher in 


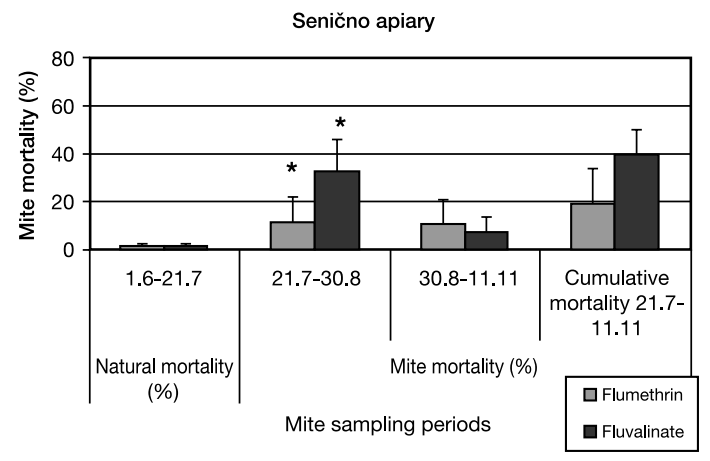

Fig. 1. The relative mite mortality (\%) of the flumethrin- and fluvalinate-treated groups in the pre-treatment periods and after the treatments in Senično (a, see above) and Lesce (b, see below) apiaries. Asterisks indicate a significant increase in mite mortality compared to the previous measurement; bars indicate standard deviation.

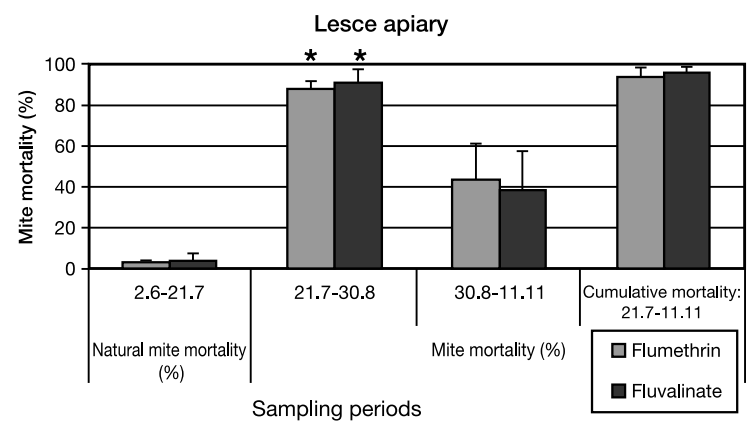

comparison to flumethrin treatment $(\mathrm{F}=14.26 ; \mathrm{df}=1 ; P<0.001)$ in Senično. The mite mortality of the flumethrin and fluvalinate applications relative to that of the OA treatments in both apiaries as well as to the pre-treatment periods are shown in Fig. 1. The percentage of mites that dropped between each of the inspections in apiary Lesce is shown in Fig. 2.

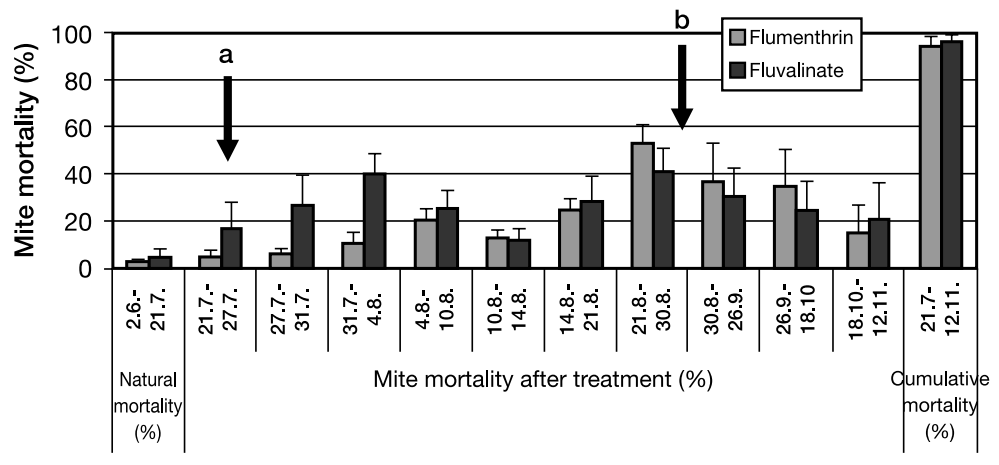

Mite treatment and sampling

Fig. 2. The relative mite mortality in Lesce apiary in each of the inspection periods. The pre-treatment natural mite mortality, the level of mortality recorded during the exposure to the medicated strips and during the post-treatment period, as well as the cumulative mite mortality are shown. The arrow a indicates the period of the flumethrin or fluvalinate strips insertion and arrow $\mathrm{b}$ indicates removal of strips; bars indicate standard deviation. 
The percentage of mite mortality after the flumethrin applications was higher in the Lesce apiary than it was in Senično $(\mathrm{F}=19.24 ; \mathrm{df}=1 ; P<0.001)$; the difference after the fluvalinate applications was also significant $(\mathrm{F}=7.29 ; \mathrm{df}=1 ; P<0.05)$.

Table 1. Average mite mortality per treatment group $( \pm \mathrm{SD})$ in the Senično and Lesce apiaries before (1.6 - 21.7), during and after flumethrin or fluvalinate treatments $(21.7-11.11)$ and after an OA treatment on November 11, 2005

\begin{tabular}{|l|c|c|c|c|}
\hline Apiary & Treatment & \multicolumn{3}{|c|}{ Mite mortality } \\
\hline & & $\begin{array}{c}1.6-21.7 \\
\text { Natural mortality }\end{array}$ & $\begin{array}{c}21.7-11.11 \\
\text { After treatment }\end{array}$ & $\begin{array}{c}11.11-8.12 \\
\text { After OA treatment }\end{array}$ \\
\hline Senično & Flumethrin & $1.75( \pm 1.34)$ & $43.43( \pm 42.07)$ & $183.88( \pm 237.89)$ \\
\hline & Fluvalinate & $2.00( \pm 2.00)$ & $65.07( \pm 31.37)$ & $100.60( \pm 268.23)$ \\
\hline Lesce & Flumethrin & $145.66( \pm 148.53)$ & $4707.16( \pm 2707.55)$ & $268.33( \pm 124.82)$ \\
\hline & Fluvalinate & $135.75( \pm 103.13)$ & $3642.25( \pm 2427.48)$ & $137.00( \pm 89.47)$ \\
\hline
\end{tabular}

\section{Discussion}

In the Senično apiary, natural mite mortality remained below 1 per day until the July treatment. This rate is low and indicates that the infestation of the colonies was slight, a fact confirmed by the total mite mortality during the experiment. The average number of mites killed during the experiment in the apiary was approximately 50 and approximately 4,200 in Lesce. The high natural mite mortality in the Lesce apiary during the pre-treatment period is indicative of a build-up of the mite population during the season (Liebig et al. 1984). A natural mite mortality rate of up to $1 \mathrm{mite} /$ day was found to indicate a mite population level that could be controlled using oxalic acid (Gregorc and Planinc 2002 and 2004a) or thymol (Gregorc 2005; Gregorc and Planinc 2004b). The flumethrin treatment in the Senično apiary initiated in July resulted in a mite mortality of approximately $20 \%$ until August 30 and mite mortality in the fluvalinate-treated colonies was $40 \%$, but in highly infested colonies in the Lesce apiary flumethrin and fluvalinate treatments trigged $94 \%$ and $96 \%$ efficacy, respectively. The high efficacy of both substances during the roughly 5-week treatment period ensured that mite reduction was sufficient enough to ensure survival during overwintering. Several tests have been performed in order to establish the efficacy of both substances. In field trials, flumethrin and fluvalinate have been found to be more than $95 \%$ effective against mites on adult bees in colonies with sealed brood (Ferrer-Dufol et al. 1995a) and even half the recommended dose has been enough to eliminate infestation (Ferrer-Dufol et al. 1995b). The overall acaricidal efficacy of flumethrin and fluvalinate $-94 \%$ and $96 \%$, respectively - continued to rise well after the medicated strips were removed from the colonies, indicating that their effects were long lasting and sufficient to ensure the survival and normal development of even highly infested colonies. While high levels of resistance to flumethrin and fluvalinate $(74-100 \%)$ have been recorded in varroa mites in the Alpine regions of Switzerland, there has been little or no resistance noted in Slovenia (18\%) and Austria (0\%) as reported by Trouiller (1998). Since then, various experiments have been conducted using organic acids or etheric oils. These organic treatments, with the exception of formic acid, can ensure the normal development of colonies with infestations resulting in less than one natural mite death per day (Gregorc and Planinc 2001, 2005; Gregorc and Poklukar 2003; Gregorc 2005). Therefore colonies with slight infestations, such as those in the Senično apiary, could be successfully treated with OA or thymol preparations. The average efficacy of an OA-solution treatment $(2.9 \% \mathrm{OA}$ and $31.9 \%$ sucrose in water) employed during the period without brood period was estimated at 98.6\% (Gregorc and Poklukar 2003), more than sufficient for a final control treatment. The efficacy of the flumethrin and fluvalinate treatments during the experiment was 
understated as it did not take into account mite reproduction within the colonies and reinvasion from neighbouring colonies; despite this the colonies developed normally.

The results of this study indicate that fluvalinate and flumethrin are both very effective in treating highly-infested honeybee colonies with sealed brood and are complementary to existing organic treatments in ensuring a sufficient degree of mite reduction during the beekeeping season.

\section{Likvidace Varroa destructor ve včelstvech včely medonosné pomocí Flumetrinu nebo Fluvalinátu}

Ve dvou včelínech, s 32 a s 15 včelstvy (Apis mellifera carnica), byla sledována mortalita roztoče před a po ošetření flumetrinem nebo fluvalinátem a po kontrolní aplikaci kyseliny štavelové. Během doby před ošetřením (42 a 51 dní) byl průměrný přirozený spad roztočù $0,04( \pm 0,04)$ a $2,82( \pm 2,19)$, což bylo $1,09 \%( \pm 1,06)$ a $3,84 \%( \pm 3,04)$ z celkového počtu roztočů zachycených během experimentu. Po aplikaci flumetrinu nebo fluvalinátu ve

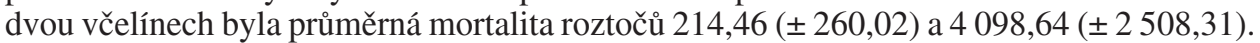
Ošetření vedlo ke snížení počtu roztočů o $19,11 \%( \pm 14,62)$ a 39,28 \% $( \pm 10,47)$ u lehce napadených včelstev a o 94,30 \% $( \pm 4,26)$ a $96,24 \%( \pm 3,14)$ u silně napadených včelstev. Rozdíl v účinnosti ošetření mezi oběma včelíny byl statisticky významný $(P<0,001)$ a ukázalo se, že fluvalinát a flumetrin jsou vysoce účinné v boji se silně napadenými včelstvy se zavíčkovaným plodem. V této studii je pojednáno o významu/důležitosti efektivní kontroly roztočů ve včelstvech s jejich vysokou přirozenou mortalitou.

\section{Acknowledgement}

This work was supported by the Slovenian Ministry of Higher Education, Science and Technology (Research programme P4-133) and the Ministry of Agriculture, Forestry and Food.

\section{References}

BRØDSGAARD CJ, JENSEN SE, HANSEN CW, HANSEN H 1999: Spring treatment with oxalic acid in honeybee colonies as varroa control. DIAS report 6, Horticulture, $16 \mathrm{p}$.

FERRER-DUFOL M, MORENO-MANERA C, MARTINEZ-VINUALES AI, SANCHEZ-ACEDO C, GRACIASALINAS MJ 1995a: Field trials of treatments against Varroa jacobsoni using fluvalinate and flumethrin strips in honey bee colonies containing sealed brood. J Apic Res 34: 147-152

FERRER-DUFOL M, MORENO-MANERA C, MARTINEZ-VINUALES AI, SANCHEZ-ACEDO C, GRACIASALINAS MJ 1995b: Diagnosis of Varroa jacobsoni in field conditions. Apicoltura 10: 23-31

FLORIS I, CABRAS P, GARAU VL, MINELLI EV, SATTA A, TROULLIER J 2001: Persistence and effectiveness of pyrethroids in plastic strips against Varroa jacobsoni (Acari: Varroidae) and mite resistance in a Mediterranean area. J Econ Entomol 94: 806-810

GREGORC A, PLANINC I 2001: Acaricidal effect of oxalic acid in honeybee (Apis mellifera) colonies. Apidologie 32: 333- 340

GREGORC A, POKLUKAR J 2003: Rotenone and oxalic acid as alternative acaricidal treatments for Varroa destructor in honeybee colonies. Vet Parasitol 111: 351-360

GREGORC A, PLANINC I 2002: The control of Varroa destructor using oxalic acid. Vet J 163: 306-310

GREGORC A, PLANINC I 2004a: Dynamics of falling varroa mites in honeybee (Apis mellifera) colonies following oxalic acid treatments. Acta Vet Brno 73: 385-391

GREGORC A, PLANINC I 2004b: Using oxalic acid for varroa mite control in honeybee colonies during the beekeeping season = Uporaba oksalne kisline za zatiranje varoj v čebeljih družinah v čebelarski sezoni. Slov Vet Res 41: 35- 39

GREGORC A 2005: Efficacy of oxalic acid and Apiguard against varroa mites in honeybee (Apis mellifera) colonies. Acta Vet Brno 74: 441-447

IMDORF A, CHARRIERE JD, BACHOFEN B 1997: Efficiency checking of the Varroa jacobsoni control methods by means of oxalic acid. Apiacta 32: 89-91

LIEBIG G, SCHLIPF U, FREMUTH W, LUDWIG W 1984: Ergebnisse der untersuchungen über die befallsentwicklung der Varroa- Milbe in Stuttgart-Hohenheim 1983. Allg Deutsch Imkerztg 6: 185-191

LODESANI M, COLOMBO M, SPREAFICO M 1995: Ineffectiveness of Apistan ${ }^{\circledR}$ treatment against the mite Varroa jacobsoni Oud. in several districts of Lombardy (Italy). Apidologie 26: 67- 72 
MELATHOPOULOS AP, GATES J 2003: Comparison of two thymol-based acaricides, Api Life Var ${ }^{\circledR}$ and Apiguard $^{\mathrm{TM}}$, for the control of Varroa mites. Amer Bee J 43: 489-493

MILANI N 1999: The resistance of Varroa jacobsoni Oud. to acaricides. Apidologie 30: 229-234

MIOZES-KOCH R, SLABEZKI Y, EFRAT H, KALEV H, KAMER Y, YAKOBSON DA 2000: First detection in Israel of fluvalinate resistance in the varroa mite using bioassay and biochemical methods. Exp Appl Acarol 24: $35-43$

MUTINELLI F, BAGGIO A, CAPILONGO F, PIRO R, PRANDIN L, BIASION L 1997: A scientific note on oxalic acid by topical application for the control of varroosis. Apidologie 28: 461- 462

SPREAFICO M, EÖRDEGH FR, BERNARDINELLI I, COLOMBO M 2001: First detection of strains of Varroa destructor resistant to coumaphos. Results of laboratory tests and field trials. Apidologie 32: 49-55

STATGRAPHICS 1991: Statistical graphic system, STSC, Rockville

TROUILLER J 1998: Monitoring Varroa jacobsoni resistance to pyrethroids in Western Europe. Apidologie 29: 537-546

WALLNER K 1999: Varroacides and their residues in bee products. Apidologie 30: 235-248

ZDEŠAR P 1998: Izdelava AŽ-panja. In: POKLUKAR J. Od čebele do medu. Založba Kmečki glas, Ljubljana, pp. 193-200 